\title{
Physiological capacity of Cancer setosus larvae - Adaptation to El Niño Southern Oscillation conditions
}

\author{
Monika Weiss ${ }^{\mathrm{a}, *}$, Olaf Heilmayer ${ }^{\mathrm{b}}$, Thomas Brey ${ }^{\mathrm{c}}$, Magnus Lucassen ${ }^{\mathrm{c}}$, Hans-Otto Pörtner ${ }^{\mathrm{c}}$ \\ a Institute for Marine Resources (IMARE), Bussestrasse 27, 27570 Bremerhaven, Germany \\ b German Aerospace Center (DLR), Heinrich-Konen-Str. 1, 53227 Bonn, Germany \\ c Alfred-Wegener-Institut für Polar- und Meeresforschung, Am Handelshafen 12, 27570 Bremerhaven, Germany
}

\section{A R T I C L E I N F O}

\section{Article history:}

Received 25 January 2011

Received in revised form 22 November 2011

Accepted 23 November 2011

Available online 29 December 2011

\section{Keywords:}

Brachyura

Citrate synthase

Early ontogeny

Metabolic enzymes

Oxygen consumption

Pyruvate kinase

\begin{abstract}
A B S T R A C T
Temperature changes during ENSO challenge the fauna of the Pacific South American coast. In many ectotherm benthic species pelagic larvae are the most important dispersal stage, which may, however, be particularly vulnerable to such environmental stress. Thermal limitation in aquatic ecotherms is hypothesized to be reflected first in the aerobic scope of an animal. Here we present results on whole animal oxygen consumption and on the activities of two metabolic key enzymes, citrate synthase (CS) and pyruvate kinase (PK)) of Cancer setosus zoeal larvae, acclimated to different temperatures. Larvae acclimated to cooler temperatures (12 and $16{ }^{\circ} \mathrm{C}$ ) were able to compensate for the temperature effect as reflected in elevated mass specific respiration rates (MSR) and enzyme activities. In contrast, warm acclimated larvae (20 and $22{ }^{\circ} \mathrm{C}$ ) seem to have reached their upper thermal limits, which is reflected in MSR decoupling from temperature and low Q10 values (Zoea I: 1.4; Zoea III: 1.02). Thermal deactivation of CS in vitro occurred close to habitat temperature (between 20 and $24^{\circ} \mathrm{C}$ ), indicating instability of the enzyme close to in vivo thermal limits. The capacity of anaerobic metabolism, reflected by PK, was not influenced by temperature, but increased with instar, reflecting behavioral changes in larval life style. Functioning of the metabolic key enzyme CS was identified to be one possible key for larval limitation in temperature tolerance.
\end{abstract}

(c) 2011 Published by Elsevier B.V.

\section{Introduction}

Temperature is often referred to as the main factor determining biogeographical distribution of marine organisms. The physiological background of temperature dependent latitudinal ranges of marine ectotherms has been subject of numerous studies and during the last decades our knowledge on temperature limitation and acclimation processes has expanded. However, most of these studies refer to adult animals. More recently, attention focused on early life stages, which are generally hypothesized to be more vulnerable to stress conditions than juveniles or young adults (Anger, 2001). Early life stages are important for species distribution and recruitment especially in benthic coastal ectotherms (Cowen and Sponaugle, 2009).

Temperature affects all levels of biological organization ranging from cellular to organism level (Guderley and St-Pierre, 2002). A mismatch between the oxygen demand of tissues and the supply by the circulatory and ventilatory system is the first mechanism restricting survival at unfavorable temperatures (Heilmayer et al., 2004; Pörtner, 2001; Pörtner, 2004; Storch et al., 2009). The thermal tolerance thresholds (pejus and critical limits) in the concept of oxygen and capacity limited thermal

\footnotetext{
* Corresponding author. Tel.: +49 4714831 2025; fax: +49 47148311149. E-mail address: monika.weiss@imare.de (M. Weiss).
}

tolerance (OCLT) presented by Pörtner et al. (2005) describe the shortage of aerobic capacity due to unfavorable temperatures. These thermal limits can be shifted by different (acclimation) mechanisms, e.g. changes in the kinetic characteristics of enzymes (Heilmayer et al., 2004; Sokolova and Pörtner, 2001).

Two temperature sensitive key enzymes regulating energy provision in the form of ATP were chosen as proxies of thermal acclimation and limitation at an enzymatic level: citrate synthase (CS) as an indicator of animal aerobic metabolism (Hochachka et al., 1970) and pyruvate kinase (PK), which represents the potential for glycolytic flux (Childress and Somero, 1979; Johnston et al., 1977; Lemos et al., 2003). Investigations on metabolic enzymes in larval stages are scarce. Studies in shrimp larvae show that CS activity is inversely correlated with growth during ontogeny (Lemos et al., 2003). Metabolic capacity thus influences crucial performances and fitness at ecosystem level.

The model species, Cancer setosus (synonymous Cancer polyodon Poeppig 1836), studied herein covers a wide latitudinal cline of about $44^{\circ}$ (Fischer and Thatje, 2008; Garth and Stephenson, 1966). The commercial value of this species for the Chilean and Peruvian artisanal fishery increased during the last decades (Sernapesca, 2006; Thatje et al., 2008; Wolff and Soto, 1992). The El Niño Southern Oscillation (ENSO), with drastically changing water temperatures between La Niña and El Niño, strongly affects the abundances and distribution range of this commercially important crab. Increasing temperatures during El Niño 
events are discussed to be one of the main factors causing mass mortalities of this species (Arntz et al., 1988). The early ontogeny, which in $C$. setosus consists of five planktotrophic zoeal stages (Zoea $\mathrm{I}-\mathrm{V}=\mathrm{Z} \mathrm{I}-\mathrm{V}$ ) and one megalopa before reaching the first crab stage (Quintana and Saelzer, 1986), is considered as the most delicate part within the life cycle of brachyuran and in particular cancrid crabs (Anger, 2001; Weiss et al., 2009a). High nutrient-content in eggs of $C$. setosus at high latitudes, supports their plasticity to respond to latitudinal and seasonal changes in temperature (Fischer et al., 2009). The relationship between environmental temperature and metabolic acclimation has been discussed in a large variety of studies, but knowledge of temperature effects on the physiology of crab larvae, especially concerning the ontogenetic development, is scarce. Furthermore, it remains speculative how larval instars are capable to compensate for the drastic temperature changes as caused by ENSO.

The present paper examines the influence of temperature on metabolism (oxygen consumption and enzyme activities) of larval $C$. setosus from the Antofagasta region in order to evaluate their capacity to respond to fluctuations in temperature as encountered by larvae during ENSO.

\section{Materials and methods}

\subsection{Sampling and maintenance of adults}

Ovigerous $C$. setosus (carapace width: female $A=12.8 \mathrm{~cm} \mathrm{CW}$, female $\mathrm{G}=14.0 \mathrm{~cm} \mathrm{CW}$ ) were caught in February 2007 by fishermen of the "Caleta Colosso" $\left(23^{\circ} 45^{\prime} \mathrm{S}, 70^{\circ} 27^{\prime} \mathrm{W}\right)$ by scuba diving and immediately transferred to the laboratory of the Instituto de Investigaciones Oceanológicas of the Universidad de Antofagasta, Chile. Animals were maintained individually in flow-through seawater aquaria (12 l) at ambient temperature $\sim 16.0{ }^{\circ} \mathrm{C}$ and salinity 34 psu in a 12:12-h light/dark cycle and fed ad libitum with living Perumytilus purpuratus.

\subsection{Experimental set-up}

Freshly hatched larvae were collected in filters receiving water from the overflow of the aquaria. Since most larvae hatched at night, samples were taken every morning. Filters were cleaned every evening to ensure daily larval age did not vary by more than $12 \mathrm{~h}$ (after Lovrich et al., 2003). Solely actively moving larvae were transferred to $100 \mathrm{ml}$ bowls with $16{ }^{\circ} \mathrm{C}$ filtered seawater and afterwards were transferred to the corresponding experimental chamber. Acclimation temperatures were chosen to simulate $\mathrm{LN}$ conditions $\left(12{ }^{\circ} \mathrm{C}\right)$, normal conditions $\left(16^{\circ} \mathrm{C}\right)$ slight EN $\left(20^{\circ} \mathrm{C}\right)$ and EN conditions $\left(22^{\circ} \mathrm{C}\right)$. For each acclimation temperature an initial number of 2000 larvae was cultured (maximum 10 individuals per bowl), water was changed daily and larvae were checked for molts or mortality and fed ad libitum with freshly hatched Artemia spp. nauplii. Larvae of female A were used for the oxygen consumption experiment and larvae of female $G$ were used for enzyme activity measurements.

\subsection{Oxygen consumption}

Randomly selected larvae of the same age from the midst of Zoea I (ZI), Zoea III (ZIII) and Zoea V (ZV) at each acclimation temperature were chosen (as available - see Table 1) for measurements of the acute temperature dependence of oxygen consumption rates. The middle of each instar period was determined by using the larval development periods described in Weiss et al., 2009a. 8 Zoea I instar larvae, 3 Zoea III larvae, and 2 Zoea $V$ larvae per replicate were transferred to an acclimation bath, where they were allowed to acclimate to the measurement temperature $\left(12,16,20\right.$ or $\left.22^{\circ} \mathrm{C}\right)$ for $20 \mathrm{~min}$ to avoid shock reactions and to exclude weak larvae (those which died during the acclimation period) from further analyses. Afterwards larvae were gently transferred into $1.0 \mathrm{ml}$
Table 1

Overview about conducted experiments. ZI, ZIII, ZV - Zoeal instars, P - postmolt, A premolt, "+" - experiment conducted, "-" - experiment not conducted due to insufficient larval material.

\begin{tabular}{|c|c|c|c|c|c|c|c|}
\hline \multirow[t]{2}{*}{ Experiment } & \multirow{2}{*}{$\begin{array}{l}\text { Acclimation } \\
\text { temperature } \\
{\left[{ }^{\circ} \mathrm{C}\right]}\end{array}$} & \multirow[t]{2}{*}{ Instar } & \multirow[t]{2}{*}{$\mathrm{n} /$ sample } & \multicolumn{4}{|c|}{$\begin{array}{l}\text { Experimental } \\
\text { temperature }\left[{ }^{\circ} \mathrm{C}\right]\end{array}$} \\
\hline & & & & 12 & 16 & 20 & 22 \\
\hline \multirow[t]{12}{*}{ Oxy } & 12 & $\mathrm{ZI}$ & 8 & + & + & + & + \\
\hline & & ZIII & 3 & - & - & + & + \\
\hline & & ZV & 2 & - & - & - & - \\
\hline & 16 & ZI & 8 & + & + & + & + \\
\hline & & ZIII & 3 & + & + & + & + \\
\hline & & ZV & 2 & - & - & - & - \\
\hline & 20 & ZI & 8 & + & + & + & + \\
\hline & & ZIII & 3 & + & + & + & + \\
\hline & & ZV & 2 & + & + & + & + \\
\hline & 22 & ZI & 8 & + & + & + & + \\
\hline & & ZIII & 3 & + & + & + & + \\
\hline & & ZV & 2 & - & - & - & - \\
\hline \multirow[t]{24}{*}{ CS } & 12 & ZIP & 10 & + & + & + & + \\
\hline & & ZIA & 6 & + & + & + & + \\
\hline & & ZIIIP & 2 & + & + & + & + \\
\hline & & ZIIIA & 2 & & & & \\
\hline & & ZVP & 1 & - & - & - & - \\
\hline & & ZVA & 1 & - & - & - & - \\
\hline & 16 & ZIP & 10 & + & + & + & + \\
\hline & & ZIA & 6 & + & + & + & + \\
\hline & & ZIIIP & 2 & + & + & + & + \\
\hline & & ZIIIA & 2 & + & + & + & + \\
\hline & & ZVP & 1 & + & + & + & + \\
\hline & & ZVA & 1 & + & + & + & + \\
\hline & 20 & ZIP & 10 & + & + & + & + \\
\hline & & ZIA & 6 & + & + & + & + \\
\hline & & ZIIIP & 2 & + & + & + & + \\
\hline & & ZIIIA & 2 & + & + & + & + \\
\hline & & ZVP & 1 & + & + & + & + \\
\hline & & ZVA & 1 & + & + & + & + \\
\hline & 22 & ZIP & 10 & + & + & + & + \\
\hline & & ZIA & 6 & + & + & + & + \\
\hline & & ZIIIP & 2 & + & + & + & + \\
\hline & & ZIIIA & 2 & + & + & + & + \\
\hline & & ZVP & 1 & - & - & - & - \\
\hline & & ZVA & 1 & - & - & - & - \\
\hline \multirow[t]{24}{*}{ PK } & 12 & ZIP & 70 & + & + & + & + \\
\hline & & ZIA & 35 & + & + & + & + \\
\hline & & ZIIIP & 15 & + & + & + & + \\
\hline & & ZIIIA & 10 & - & - & - & - \\
\hline & & ZVP & 3 & - & - & - & - \\
\hline & & ZVA & 2 & - & - & - & - \\
\hline & 16 & ZIP & 70 & + & + & + & + \\
\hline & & ZIA & 35 & + & + & + & + \\
\hline & & ZIIIP & 15 & + & + & + & + \\
\hline & & ZIIIA & 10 & + & + & + & + \\
\hline & & ZVP & 3 & - & - & - & - \\
\hline & & ZVA & 2 & - & - & - & - \\
\hline & 20 & ZIP & 70 & + & + & + & + \\
\hline & & ZIA & 35 & + & + & + & + \\
\hline & & ZIIIP & 15 & + & + & + & + \\
\hline & & ZIIIA & 10 & + & + & + & + \\
\hline & & ZVP & 3 & + & + & + & + \\
\hline & & ZVA & 2 & + & + & + & + \\
\hline & 22 & ZIP & 70 & + & + & + & + \\
\hline & & ZIA & 35 & + & + & + & + \\
\hline & & ZIIIP & 15 & + & + & + & + \\
\hline & & ZIIIA & 10 & + & + & + & + \\
\hline & & ZVP & 3 & - & - & - & - \\
\hline & & ZVA & 2 & - & - & - & - \\
\hline
\end{tabular}

glass caps with fully aerated seawater and sealed with silicon membrane lids. Care was taken that no air bubbles were enclosed. Oxygen microoptodes (needle-type, fiber-optic microsensor, flat broken tip, $140 \mu \mathrm{m}$ ) were inserted through the silicon membranes into the glass caps. Each measurement consisted of 3 replicates and 1 blank (glass cap filled with aerated seawater). Blanks were run in order to correct for bacterial oxygen consumption. Each combination of temperature and larval instar 
was tested 3 times (see Table 1). The caps and the optodes were fixed in a mounting rack, which was placed into the temperature controlled basin. Optodes were connected to a 4-channel microsensor oxygen meter (PreSens $\mathrm{GmbH}$, Regensburg, Germany), and oxygen was continuously recorded once every $15 \mathrm{~s}$ until depletion occurred by a minimum of $5 \%$ oxygen. During the experiments the experimental setup was gently shaken once every 5 min to avoid the development of oxygen gradients within the glass caps. Prior to experiments, optodes were calibrated with aerated seawater (see above) for $100 \%$ oxygen, and with a saturated sodium dithionite $\left(\mathrm{Na}_{2} \mathrm{~S}_{2} \mathrm{O}_{4}\right)$ solution for $0 \%$ oxygen. Experimental temperatures were kept constant $\left( \pm 0.5^{\circ} \mathrm{C}\right)$ in temperature controlled water baths.

\subsection{Enzyme assays}

Samples for the determinations of enzyme activities of citrate synthase (CS) and pyruvate kinase (PK) were taken in the post- $(P)$ and premolt (A) period of the Zoea I (ZIP, ZIA), Zoea III (ZIIIP, ZIIIA) and Zoea V (ZVP, ZVA) instar of larvae reared at the four acclimation temperatures $\left(12,16,20,22^{\circ} \mathrm{C}\right)$ and analyzed following a modified method of Sidell et al. (1987) (CS) and a modified method of Simpfendörfer et al. (1995) (PK), which were adopted for small sample size and measurement in a microplate reader. Three replicates were collected for each "instar $\times$ acclimation temperature" combination as available (see Table 1 ).

Frozen samples were homogenized in extraction buffer $(75 \mathrm{mM}$ Tris- $\mathrm{HCl}, 1 \mathrm{mM}$ EDTA; pH 7.6) at a ratio of $\sim 0.3 \mu \mathrm{l}$ per $1 \mu \mathrm{g}$ larval $D W$ (dry weight) to get a $1: 3(\mathrm{w} / \mathrm{v})$ ratio with a Branson Sonifier $450\left(0^{\circ} \mathrm{C}\right.$, output control 8, duty cycle $\left.50 \%, 15 \mathrm{~min}\right)$. Cell debris was removed by centrifugation for $5 \mathrm{~min}$ at $7400 \mathrm{~g}$ and $0{ }^{\circ} \mathrm{C}$ with an Eppendorf centrifuge 5810R.

\subsubsection{Protein content}

The concentration of soluble protein in the extracts was measured according to Bradford (Bradford, 1976). The samples were diluted 1:5 with $0.9 \% \mathrm{NaCl}$ before being applied in duplicate $(5 \mu \mathrm{l})$ on microplates. Subsequently $250 \mu \mathrm{l}$ dye reagent (Biorad protein assay 5000006, diluted 1:5 with aqua dest) were added and the optical density was measured at $620 \mathrm{~nm}$ in a microplate reader (FLUOstar Galaxy, BMG). Bovine serum albumin (BSA, 0-3.5 $\mu$ g per well) was run in parallel as standard.

\subsubsection{Citrate synthase}

Citrate synthase (CS) (E.C. 4.1.3.7) is a key regulatory enzyme in the tricarboxylic acid (TCA) cycle and was chosen as an indicator of aerobic capacity. Due to the limited volume of extract the assay according to Sidell et al., 1987 was adapted for use in a microplate reader and under controlled (below ambient) temperature conditions.

Homogenates $(2 \mu \mathrm{l} /$ well $)$ were assayed in $200 \mu \mathrm{l}$ of $75 \mathrm{mM}$ Tris- $\mathrm{HCl}$ buffer ( $\mathrm{pH}$ 8.0), 0.25 mM DTNB (5.5'-dithio-bis-(2-nitrobenzoic acid)) and $0.4 \mathrm{mM}$ acetyl-CoA. $0.4 \mathrm{mM}$ oxalacetate was added to start the reaction (omitted for the blanks).The microplates were incubated at the respective temperature $\left(12,16,20,22,28{ }^{\circ} \mathrm{C}\right)$ on a thermostated aluminum block (constructed by E. Dunker, Alfred Wegener Institute Bremerhaven); and the development of free $\mathrm{SH}$ groups was measured quickly every $5 \mathrm{~min}$ for $30 \mathrm{~min}$ ( 6 measurements) in a microplate reader at $405 \mathrm{~nm}$ and room temperature after which time the plate was returned to the aluminum block for further incubation. Enzyme activity in units per mg protein ( $\mathrm{U} \mathrm{gprt}^{-1}$ ) was calculated using a standard curve produced with dithiothreitol (DTT) corresponding to 25 to $200 \mu \mathrm{M}$ SH groups.

\subsubsection{Pyruvate kinase}

Pyruvate kinase (PK) (EC 2.7.1.40) catalyzes the last step of the glycolytic pathway which is the transphosphorylation from phosphoenolpyruvate and ADP to pyruvate and ATP. Hence, PK activity may represent the potential for anaerobic work in the glycolytic pathway (Johnston et al., 1977). Again, the assay according to Simpfendörfer et al. (1995) was adapted for use in a microplate reader below ambient temperature. Homogenates ( $10 \mu \mathrm{l} /$ well $)$ were assayed in $200 \mu \mathrm{l}$ of assay buffer ( $\mathrm{pH}$ 8.0) $\left(6 \mathrm{mM}\right.$ Tris- $\mathrm{HCl}, 60 \mathrm{mM} \mathrm{KCl}, 6 \mathrm{mM} \mathrm{MgSO}{ }_{4} \times 7 \mathrm{H}_{2} \mathrm{O}$ ) $7 \mathrm{mM}$ NADH, $0.5 \mathrm{mM}$ PEP and $5.5 \mathrm{U} / \mathrm{ml} \mathrm{LDH}$. $1 \mathrm{mM}$ ADP was added to start the reaction (omitted for the blanks). Standards of $7 \mathrm{mM} \mathrm{NADH}$ (2-10 $\mu \mathrm{l}$ per well) were run in parallel. The microplates were incubated at the respective temperature $\left(12,16,20,22,28^{\circ} \mathrm{C}\right)$ on a thermostated aluminum block; and the coupled oxidation of NADH was measured quickly every $5 \mathrm{~min}$ for $30 \mathrm{~min}$ (6 measurements) in a microplate reader at $340 \mathrm{~nm}$ and room temperature after which time the plate was returned to the aluminum block for further incubation. Enzyme activity in units per mg protein $\left(\mathrm{Ugprt}^{-1}\right)$ was calculated using a standard curve produced from NADH $(0.5 \mathrm{mM})$ and corresponding to 7 to $35 \mu \mathrm{M}$ NADH groups.

\subsection{Statistical analyses}

All data were tested with the Jackknife distance test (Kezdi et al., 2002) to exclude outliers from analysis. The effect of acclimation temperature $T_{a}$, measurement temperature $T_{m}$ (Kelvin) and body mass $D W$ ( $\mu$ g dry mass) on metabolic activity (oxygen consumption, CS activity, PK activity) was assessed by means of analysis of covariance (ANCOVA) according to the model

$$
\ln (\text { rate })=a+b_{1} / T_{m}+b_{2} * \ln (D W)+D_{1}+D_{2} / T_{m}
$$

where variables $D_{1}$ and $D_{2}$ attain values specific for $T_{a}(12,16,20$, $22{ }^{\circ} \mathrm{C}$ ). Only the significant terms of each model are presented in the Results chapter. The relationship between $\ln$ (CS activity) and the inverse of $T_{m}$ was not linear over the whole temperature range, i.e. this model could not be applied (see Results). Instead, we introduced $T_{m}$ as a categorial variable to test for effects of $W$ and of $T_{a}$.

\section{Results}

\subsection{Oxygen consumption}

Larval oxygen consumption is predicted from measurement temperature $\left(T_{m}\right)$, acclimation temperature $\left(T_{a}\right)$ and larval body mass $(D W)$ by the model

$$
\begin{aligned}
\ln (\text { Oxy })= & 8.8781-4207.9393 * 1 / T_{m}-0.0885 * \ln (D W)+D_{1} \\
& +D_{2} /\left(T_{m}-0.0034\right)
\end{aligned}
$$

where $\mathrm{D}_{1}=0.0678,-0.0953 ; 0.0153 ; 0.0122$ and $\mathrm{D}_{2}=-2154.3805$; $-1001.2125 ; 1102.7057 ; 2052.8873$ for $T_{a}=12,16,20,22^{\circ} \mathrm{C}$.

$\mathrm{N}=256, \mathrm{~F}=15.112, \mathrm{R}^{2}=0.33$, and $\mathrm{p}<0.0001$ for the whole model and each term. Please note that $1 / T_{m}$ is adjusted to mean $=$ zero in the interaction term in order to make the test for the main effects independent of the test for interaction ("centered polynomials").

Note that the model (Fig. 1) predicts larval oxygen consumption for just any combination of larval body mass and measurement temperature; whereas our experiments indicate that the "body mass $x$ temperature" space where larvae perform aerobically is limited (see Discussion). Outside the pejus range larval oxygen consumption rates will most probably level off.

In general whole organism oxygen consumption of $C$. setosus larvae increased with progressing development. However, depending on acclimation temperatures the increase varied without any discernible pattern. Mass specific respiration rates (MSR) showed significant differences between acclimation temperatures $(p=0.040, F=2.81$, $\mathrm{df}=3)$, measurement temperature $(\mathrm{p}<0.0001, \mathrm{~F}=84.60, \mathrm{df}=1)$, body mass $(\mathrm{p}=0.0002, \mathrm{~F}=14.38, \mathrm{df}=1)$ and in the interaction term of and "acclimation temperature $\times$ measurement temperature" $(p=0.0086$, 


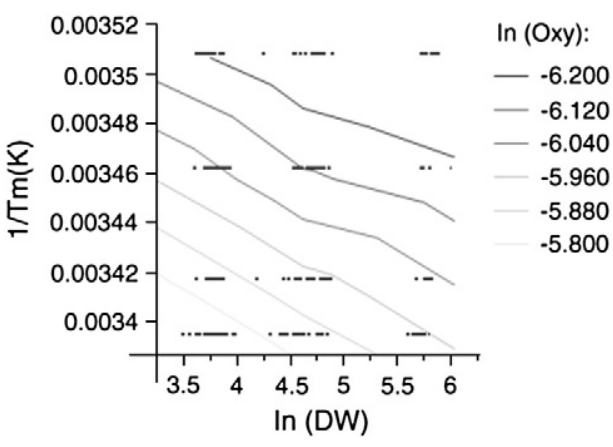

Fig. 1. Model of oxygen consumption of larval Cancer setosus throughout their development. Points show real data. Equation for the model is: $\ln (\mathrm{Oxy})=8.8781$ $4207.9393 \times 1 / T_{m}-0.00885 \times \ln (D W)+D_{1}+D_{2} /\left(T_{m}-0.0034\right) .(\mathrm{N}=256, \mathrm{~F}=15.112$ $\left.\mathrm{R}^{2}=0.33, \mathrm{p}<0.0001\right) . T_{m}$ represents the measurement temperature in Kelvin, $T_{a}$ represents the acclimation temperature of larvae and $D W$ is the body mass in dry weight $(\mu \mathrm{g})$. Isolines represent the oxygen consumption in $\left(\mu \mathrm{mol} * \mathrm{day}^{-1} * D W^{-1}\right)$. For further details see text.

$\mathrm{F}=3.97, \mathrm{df}=3)$. As expected, MSR of larvae increase with measurement temperature. Thermal sensitivity of oxygen turnover (expressed as Q10) decreased with increasing acclimation temperature from 2.3 at $12{ }^{\circ} \mathrm{C}$ acclimated Zoea I larvae to 1.4 in $22^{\circ} \mathrm{C}$ acclimated larvae (data not shown). This decrease is even more pronounced in ZIII larvae, showing a Q10 of 2.28 at an acclimation temperature of $16{ }^{\circ} \mathrm{C}$ and a $\mathrm{Q} 10$ of 1.02 at $22{ }^{\circ} \mathrm{C}$ acclimation temperature.

\subsection{Citrate synthase}

The citrate synthase (CS) activity of $C$. setosus larvae differed significantly depending on acclimation temperature $(p=0.0003$, $\mathrm{F}=6.34, \mathrm{df}=3)$, assay temperature $(\mathrm{p}<0.0001, \mathrm{~F}=21.20, \mathrm{df}=1)$ and body mass $(\mathrm{p}=0.0007, \mathrm{~F}=11.56, \mathrm{df}=1)$. CS activity was found to be highest at an acclimation temperature of $12{ }^{\circ} \mathrm{C}$, and remained virtually unchanged at the higher acclimation temperatures. The CS activity increased with increasing assay temperature, until about 20 to $22^{\circ} \mathrm{C}$ but was significantly lower at the assay temperature of $28^{\circ} \mathrm{C}$ (Fig. 2) which is also reflected in different Q10 values for the lower $\left(12-20^{\circ} \mathrm{C}\right.$, Q10: $1.5 \pm 0.36)$ and upper temperature range $\left(20-28{ }^{\circ} \mathrm{C}, \mathrm{Q} 10: 0.45 \pm\right.$ $0.15)$, the latter indicating thermal inactivation of the enzyme.
The CS activity decreases with increasing body size. The number of assay temperatures did not allow exact calculations of Arrhenius breakpoint temperatures (ABT) with acclimation temperature and instar. Nevertheless, the ABT of CS seems to be located between 20 and $24{ }^{\circ} \mathrm{C}$, as seen in the Arrhenius plot (Fig. 2).

\subsection{Pyruvate kinase}

Larval PK activity is predicted best from measurement temperature $\left(T_{m}\right)$ and larval body mass $(D W, \mu \mathrm{g})$ by the model

$\ln (P K)=11.8344-4158.7783 * 1 / T_{m}+0.1469 * \ln (D W)$

$\mathrm{N}=844, \mathrm{~F}=548.09, \mathrm{R}^{2}=0.57$, and $\mathrm{p}<0.0001$ for both slopes and for the whole model. PK activity showed a continuous increase with measurement temperature (Fig. 3). The Q10 values were lower for freshly hatched larvae (ZIP, Q10: 1.17) than for ZI larvae in the premolt phase (ZIA: $1.83 \pm 0.14$ ), but in ZIII and ZV Q10 values are higher in the postmolt phase than during the premolt phase (ZIIIP, Q10: $1.86 \pm 0.097$; ZIIIA, Q10: $1.34 \pm 0.722 ;$ ZVP, Q10: 1.41; ZVA, Q10: 1.39$)$. PK activity increased continuously with body mass, with slightly higher values in the beginning of the ZIIIA and ZVA instar than at the end of the corresponding instar.

The CS/PK ratio was determined for 16 and $20^{\circ} \mathrm{C}$, temperatures which supported complete zoeal development. Here the CS/PK ratio was not dependent on acclimation temperature, but values decreased significantly from Zoea I to Zoea $\mathrm{V}(\mathrm{p}<0.0001 ; \mathrm{N}=65 ; \mathrm{df}=5 ; \mathrm{F}=8.65)$.

\section{Discussion}

Temperature limitations of $C$. setosus larvae were found to be reflected in the functioning and activity of the metabolic key enzyme CS. Our results indicate that larvae undergo cold acclimation associated with an activity increase of CS at an acclimation temperature of $12{ }^{\circ} \mathrm{C}$. The onset of a thermal deactivation of the enzyme within homogenates was detected between 20 and $24{ }^{\circ} \mathrm{C}$. Similar temperature effects on larval metabolism could also be found in the MSR, which show high values in cold acclimated larvae $\left(12^{\circ} \mathrm{C}\right)$ and a leveling off in the thermal response indicating capacity limitation at higher temperatures $\left(20\right.$ and $\left.22^{\circ} \mathrm{C}\right)$.

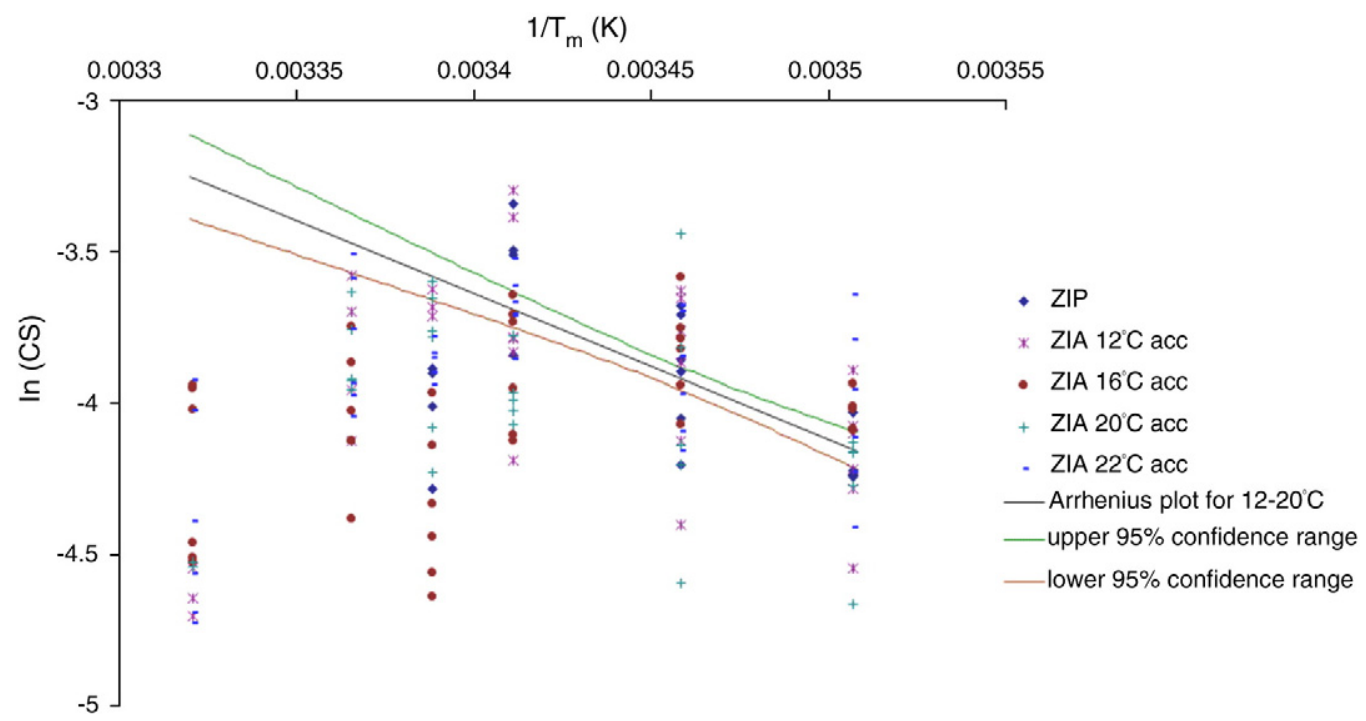

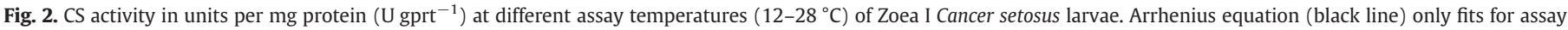

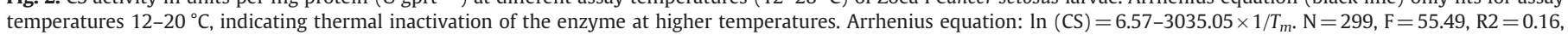
$\mathrm{p}<0.0001$. Green and brown lines are indicating the upper and lower 95\% confidence range. 


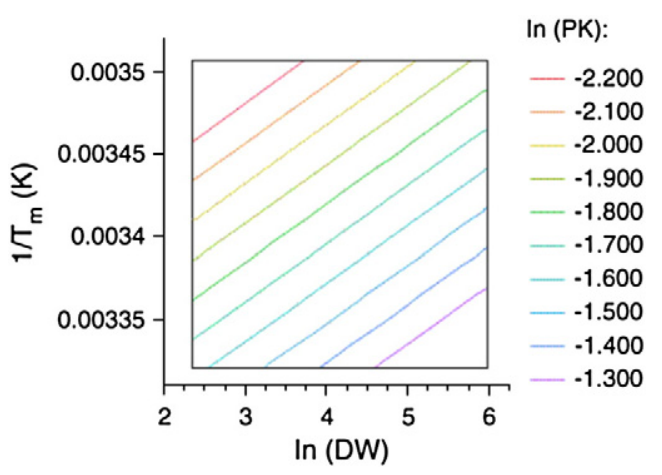

Fig. 3. Model of PK activity of larval Cancer setosus throughout their development. Equation for the model is: $\ln (\mathrm{PK})=11.8344-4158.7783 \times 1 / T_{m}+0.1469 \times \ln (\mathrm{DW})$. $\mathrm{N}=844, \mathrm{~F}=548.09, \mathrm{R} 2=0.57, \mathrm{p}<0.0001$ for the whole model. $T_{m}$ represents the measurement temperature in Kelvin and $D W$ is the body mass in dry weight ( $\mu \mathrm{g})$. Isolines represent the PK activity in units per mg protein $\left(\mathrm{U} \mathrm{gprt}^{-1}\right)$.

Standard metabolic rate of an organism typically increases exponentially with increasing temperature between critical temperatures, which border the wider thermal tolerance window including the passive range until anaerobic metabolism sets in (Pörtner et al., 2005). As Zoea larvae are actively swimming in the water column, larval oxygen consumption comprises standard metabolism and oxygen demand for swimming, and can be best described as routine metabolism. Although an exponential pattern of routine metabolism could not be observed in larvae of the congener Cancer irroratus (Sastry, 1979) and other decapod larvae such as Taliepus dentatus (Storch et al., 2009), swimming C. setosus larvae obviously display an exponential increase of their routine metabolism with increasing temperature (see Fig. 1). The window between critical limits of swimming larvae would thus result narrower than in the resting larvae.

The developed model (Fig. 1) allows us to predict the MSR of C. setosus larvae for any combination of body mass and measurement temperature, but experiments indicate a limitation of the aerobic performance.

As expected, mass specific oxygen consumption decreases with body mass. Interestingly the slope of this decrease is much lower $(-0.08)$ than expected theoretically and as we know from empirical data $(-0.25)$. An almost linear increase of individual respiration rates with $D W$ normally is only found during periods of increased growth (Heilmayer et al., 2004; Hoegh-Guldberg and Manhan, 1995). This finding is also reflected in the extremely high cumulative growth rates of C. setosus larvae (Weiss et al., 2009a) when compared to other decapod crustacean larvae (Anger, 1995). When acclimated to higher temperatures (20 and $22^{\circ} \mathrm{C}$ ) larval routine oxygen consumption failed to increase with measurement temperature, demonstrated in low Q10 values at higher acclimation temperatures (see Results). Part of this loss in thermal response may be due to reduced metabolism. This indicates that aerobic larval metabolism of warm acclimated animals is reaching its upper limit and has no or only very limited capacities to adjust to further temperature increments. As stated by Hoegh-Guldberg and Pearse (1995) a lack of temperature compensation indicates that larval development occurs close to the upper possible temperature limit. In cold acclimated larvae a higher thermal plasticity was found, indicated by higher Q10 values well within the thermal range. Zoea III acclimated at $12{ }^{\circ} \mathrm{C}$ show particularly high oxygen consumption rates and corresponding high levels of CS activity.

An elevated CS activity at cold temperatures indicates metabolic cold compensation (Lemos et al., 2003; Sokolova and Pörtner, 2001). CS activity measured at different assay temperatures increased with increasing temperature before declining in vitro at temperatures warmer than $20^{\circ} \mathrm{C}$ (Fig. 2), indicating onset of thermal deactivation of the enzyme. Such deactivation is manifest in reduced activities in all groups at $28{ }^{\circ} \mathrm{C}$ assay temperature even when compared to $12{ }^{\circ} \mathrm{C}$ assay temperature. This means that the temperature optimum for the functioning of CS lies close to the optimum temperature for larval development and growth $\left(\sim 20^{\circ} \mathrm{C}\right)$ (Weiss et al., 2009a) in the Antofagasta region. Although denaturation temperatures are usually found far beyond the naturally experienced temperatures of (temperate and cold-water) ectotherms (Sokolova and Pörtner, 2001) as supported by the present PK data, a similar discontinuity in CS activity has been described for Littorina saxatilis, where the deactivation temperature of the enzyme in vitro lies equally close to the high ambient temperatures encountered by the animal (Sokolova and Pörtner, 2001). This suggests that the failure of CS at high temperatures may substantially contribute to the thermal limitation of larvae.

The functioning of CS is restricted in all larval instars. Our results also indicate that the ABTs of CS in higher instars of warm acclimated larvae are shifted to warmer temperatures. Further investigations with even more assay temperatures are needed to substantiate this finding. Such a shift in ABT with acclimation temperature may suggest that higher instars show a certain capability for warm acclimation and are therefore less vulnerable to elevated temperatures. This may correspond with the local oceanographic conditions in the experimental region, where younger larvae most likely drift into the Antofagasta bay and are retained within a cyclonic current at elevated temperatures for longer periods of time. According to the present data an acclimation of the CS properties occurs under the local conditions in the experimental area. This may support elevated instar dependent temperature optima of growth rates in C. setosus Zoea II + III instars (Weiss et al., 2009a).

In light of the temperature changes associated with ENSO Zoea I instars display very limited tolerance as indicated by the lack of thermal compensation in respiration rates and the low denaturation temperature of CS, (sensu Sokolova and Pörtner, 2001) The ABT of CS between 20 and $24{ }^{\circ} \mathrm{C}$ (Fig. 2) (Table 5) indicates thermal inactivation of CS closely preceding the acute lethal limit of $C$. setosus Zoea I larvae, which lies between $>24$ and $<30{ }^{\circ} \mathrm{C}$ (Weiss et al., 2009b and preliminary experiments). Thus, the dysfunction of mitochondrial enzymes and more generally a loss in aerobic capacity may contribute to mortality under acute heat stress, as during EN events, especially in warm water regions like the Antofagasta bight.

The moderate warm acclimation capacity of the larvae matches the slight seasonal temperature variations of $\sim 4{ }^{\circ} \mathrm{C}$ (SHOA, 2009) in Antofagasta, more than the larger (up to $10^{\circ} \mathrm{C}$ ) temperature fluctuations associated with EN events. Oxygen consumption measurements and recent studies of elemental composition and phenotypic plasticity of body size and spine characteristics (Weiss et al., 2009a; Weiss et al., 2009b) indicate that $C$. setosus larvae already reach their thermal limits at $\sim 22^{\circ} \mathrm{C}$.

$\mathrm{CS}$ activity is changing in vivo depending on the instar and is clearly declining towards the Zoea V (Table 5). A decline in CS activity through ontogenetic development can be related to the 450 -fold increase in body size (Weiss et al., 2009a) and thus allometric effects from instar to instar. Another reason for this decrease may lie in the reduced requirement for locomotory activity and therefore aerobic capacity after transition from planktonic to benthic life style which occurs within the megalopa (Lemos et al., 2003).

In contrast to CS activities, pyruvate kinase (PK) activities were not affected by acclimation temperature indicating that PK is not contributing to thermal compensation or displays sufficient capacity at any acclimation temperature. PK activity increased continuously with assay temperature from 12 to $28^{\circ} \mathrm{C}$, with no signs of thermal inactivation (Fig. 2). PK activity increased with increasing larval size, and thus the CS/PK ratios decreased with increasing instar, as would be expected from allometric relationships. Higher glycolytic over TCA (tricarboxylic acid) capacities in later larval instars indicate higher capacities for anaerobic metabolism. These findings correspond with larval life styles, as they improve their capacity to hunt prey and escape from predators during their ontogeny (Lemos et al., 2003). Furthermore, higher PK over CS activities at higher temperatures indicate a strategy to stabilize energy metabolism by use of 
anaerobic capacities which help to survive short-term thermal extremes.

In higher instars (ZIII and ZV) PK activity is more pronounced in the beginning of the instar than in the end (also reflected by Q10 values higher in the beginning of an instar than in the end), which may indicate low PK activity during ecdysis. During the premolt phase food uptake is stopped, which obviously weakens the larvae, as visible in the CHN values and the high mortality during ecdysis (Weiss et al., 2009a). Low PK activity during the energy consuming molt shows that larvae can only revert to a limited anaerobic capacity, which in total may contribute to the high mortality of larvae during ecdysis.

\section{Conclusion}

C. setosus zoeal instars show high temperature sensitivity in aerobic metabolism. Respiratory and CS capacities show compensation in the cold but are limited at warmer temperatures. Anaerobic capacities display no compensation, but a higher anaerobic than aerobic capacity may be associated with slowing larval life style. Later in ontogeny when the capacity to forage by hunting improves, PK activity rises indicating higher capacities for anaerobic metabolism.

The results of this study indicate that $C$. setosus larvae are able to display a certain thermal compensation in the cold, but larvae obviously already live at their upper tolerance limits. Limitation of aerobic metabolic pathways seems to be responsible for a restricted thermal tolerance of $C$. setosus larvae during EN events.

\section{Acknowledgments}

We would like to thank M. Oliva (Universidad Antofagasta) for providing workspace in his laboratory. This study is conducted in the frame of the EU-FP6-INCO project CENSOR (Climate variability and El Niño Southern Oscillation: Implications for natural coastal resources and management) (contract no. 511071), and received additional funding from the Marine Biodiversity and Ecosystem Functioning Network of Excellence MarBEF (contract no. GOCE-CT-2003-505446). MW was supported by a travel grant of the DAAD (contract no. $415 \mathrm{D} / 07 / 47120$ ). [SS]

\section{References}

Anger, K., 1995. The conquest of freshwater and land by marine crabs: adaptations in lifehistory patterns in larval bioenergetics. J. Exp. Mar. Biol. Ecol. 193 (1-2), 119-145.

Anger, K., 2001. The Biology of Decapod Crustacean Larvae. A.A. Balkema Publishers, Lisse. Crustacean Issues 14.

Arntz, W.E., Valdivia, E., Zeballos, J., 1988. Impact of El Niño 1982-83 on the commercially exploited invertebrates (mariscos) of the Peruvian shore. Meeresforschung/ Rep. Mar. Res. 32 (1), 3-22.

Bradford, M.M., 1976. A rapid and sensitive method for the quantification of microgram quantities of protein utilizing the principle of protein-dye binding. Anal. Biochem. $72(1-2), 248-254$.

Childress, J.J., Somero, G.N., 1979. Depth-related enzymic activities in muscle, brain and heart of deep-living pelagic marine teleosts. Mar. Biol. 52 (3), 273-283.

Cowen, R.K., Sponaugle, S., 2009. Larval dispersal and marine population connectivity. Annu. Rev. Mar. Sci. 1, 443-466.

Fischer, S., Thatje, S., 2008. Temperature-induced oviposition in the brachyuran crab Cancer setosus along a latitudinal cline: aquaria experiments and analysis of fielddata. J. Exp. Mar. Biol. Ecol. 357 (2), 157-164.
Fischer, S., Thatje, S., Brey, T., 2009. Early egg traits in Cancer setosus (Decapoda, Brachyura) from Northern and Central-Southern Chile: effects of temperature and maternal size. Mar. Ecol. Prog. Ser. 377, 193-202.

Garth, J.S., Stephenson, W., 1966. Brachyura of the Pacific coast of America, Brachyrhyncha: Portunidae. Allan Hancock Monographs in Marine Biology, 1. Allan Hancock Foundation, University of Southern California, Los Angeles.

Guderley, H., St-Pierre, J.S., 2002. Going with the flow or life in the fast lane: contrasting mitochondrial responses to thermal change. J. Exp. Biol. 205 (15), 2237-2249.

Heilmayer, O., Brey, T., Poertner, H.O., 2004. Growth efficiency and temperature in scallops: a comparative analysis of species adapted to different temperatures. Funct. Ecol. 18 (5), 641-647.

Hochachka, P.W., Somero, G.N., Schneider, D.E., Freed, J.M., 1970. The organization and control of metabolism in the crustacean gill. Comp. Biochem. Physiol. 33, 529-548.

Hoegh-Guldberg, O., Manhan, D.T., 1995. Coulometric measurement of oxygen consumption during development of marine invertebrate embryos and larvae. Jour. Exp. Biol. 198, 19-30.

Hoegh-Guldberg, O., Pearse, J.S., 1995. Temperature, food availability, and the development of marine invertebrate larvae. Am. Zool. 35 (4), 415-425.

Johnston, I.A., Davison, W., Goldspink, G., 1977. Energy metabolism of carp swimming muscles. J. Comp. Physiol. 114 (2), 203-216.

Kezdi, G., Hahn, J., Solon, G., 2002. Jackknife minimum distance estimation. Econ. Lett. 76 (1), 35-45 (11).

Lemos, D., Salomon, M., Gomes, V., Phan, V.N., Buchholz, F., 2003. Citrate synthase and pyruvate kinase activities during early life stages of the shrimp Farfantepenaeus paulensis (Crustacea, Decapoda, Penaeidae): effects of development and temperature. Comp. Biochem. Physiol. B: Biochem. Mol. Biol. 135 (4), 707-719.

Lovrich, G.A., Thatje, S., Calcagno, J.A., Anger, K., Kaffenberger, A., 2003. Changes in biomass and chemical composition during lecithotrophic larval development of the southern king crab, Lithodes santolla (Molina). J. Exp. Mar. Biol. Ecol. 288 (1), 65-79.

Pörtner, H.O., 2001. Climate change and temperature-dependent biogeography: oxygen limitation of thermal tolerance in animals. Naturwissenschaften 88 (4), 137-146.

Pörtner, H.O., 2004. Climate variability and the energetic pathways of evolution: the origin of endothermy in mammals and birds. Physiol. Biochem. Zool. 77 (6), 959-981.

Pörtner, H.O., Lucassen, M., Storch, D., 2005. Metabolic biochemistry: its role in thermal tolerance and in the capacities of physiological and ecological function. Fish. Physiol. 22, 79-154.

Quintana, R., Saelzer, H., 1986. The complete larval development of the Edible Crab, Cancer setosus Molina and observations on the prezoeal and first zoeal stages of C. coronatus Molina (Decapoda: Brachyura, Cancridae). Jour. Fac. Sci. Hokkaido. Univ. Ser. VI Zool. 24 (4), 267-303.

Sastry, A.N., 1979. Metabolic adaptation of Cancer irroratus developmental stages to cyclic temperatures. Mar. Biol. 51 (3), 242-250.

Sernapesca, 2006. Servicio Nacional de Pesca, Chile. www.sernapesca.cl2006.

SHOA, 2009. Servicio Hidrográfico y Oceanographico de la armada de Chile. www. shoa.cl2009.

Sidell, B.D., Driedzic, W.R., Stowe, D.B., Johnston, I.A., 1987. Biochemical correlations of power development and metabolic fuel preferenda in fish hearts. Physiol. Zool. 60 (2), 221-232.

Simpfendörfer, R.W., Vial, M.V., Lopez, D.A., Verdala, M., Gonzalez, M.L., 1995. Relationship between the aerobic and anaerobic metabolic capacities and the vertical distribution of three intertidal sessile invertebrates: Jehlius cirratus (Darwin) (Cirripedia), Perumytilus purpuratus (Lamarck) (Bivalvia) and Mytilus chilensis (Hupe) (Bivalvia). Comp. Biochem. Physiol. B 111B (4), 615-623.

Sokolova, I.M., Pörtner, H.O., 2001. Temperature effects on key metabolic enzymes in Littorina saxatilis and L. obtusata from different latitudes and shore levels. Mar. Biol. 139 (1), 113-126.

Storch, D., Santelices, P., Barria, J., Cabeza, K., Pörtner, H.O., Fernández, M., 2009. Thermal tolerance of crustacean larvae (Zoea I) in two different populations of the kelp crab Taliepus dentatus (Milne-Edwards). J. Exp. Biol. 212, 1371-1376.

Thatje, S., Heilmayer, O., Laudien, J., 2008. Climate variability and El Niño Southern Oscillation: implications for natural coastal resources and management. Helgol. Mar. Res. 62 (1), 5-14

Weiss, M., Heilmeyer, O., Brey, T., Thatje, S., 2009a. Influence of temperature on the zoeal development and elemental composition of the cancrid crab, Cancer setosus Molina, 1782 from Pacific South America. J. Exp. Mar. Biol. Ecol. 376 (1), 48-54.

Weiss, M., Thatje, S., Heilmayer, O., 2009b. Temperature effects on zoeal morphometric traits and intraspecific variability in the hairy crab Cancer setosus across latitude. Helgol. Mar. Res. 64 (2), 125-133.

Wolff, M., Soto, M., 1992. Population dynamics of Cancer polyodon in La Herradura Bay, northern Chile. Mar. Ecol. Prog. Ser. 85, 69-81. 